\title{
Pollutant Removal from Highway Runoff Using Retention/Detention Units
}

\begin{abstract}
Ashraf El-Shahat Elsayed, A. Grünwald, D. Dvořák
Highway runoff contains total suspended solids, hydrocarbons, oil and greases, chloride, and other contaminants that are transported in solution and particulate forms to adjacent floodplains, roadside swales, and retention/detention ponds. Oil and grit chambers represent a type of retention/detention unit used for removing heavy particulates and adsorbed hydrocarbon particulates. Storage/sediment units also represent a type of retention/detention unit used for controlling peak flow and removing suspended solids. The aim of this study is to evaluate the effect of traffic volume and site characteristics on highway runoff quality. The study also aims to evaluate the performance of retention/detention units that collect runoff from the Prague-Brno and Prague-Plzen highways, Czech Republic. The results of this study indicate no definitive relationship between average daily traffic and concentration of runoff constituents, though the site characteristics have a strong relation to some constituents. The results also show that retention/detention units are effective in treating organic compounds.
\end{abstract}

Keywords: highway runoff, oil/grit chambers, sedimentation, suspended solids, organic.

\section{Introduction}

Highway operation and maintenance contribute a variety of pollutant constituents to surface and subsurface water. Numerous factors may affect the presence of these constituents and the quality of highway runoff, including: traffic volume, precipitation characteristics, roadway surface type, the nature of the pollutants themselves, surrounding land use, and seasonal considerations. Highway runoff contains total suspended solids, hydrocarbons, oil and greases, chloride, and other contaminants that are transported in solution and particulate forms to adjacent floodplains, roadside swales, and retention/detention ponds. The use of retention/detention units for storage and attenuation of peak flows is well established, but their effectiveness in removing highway runoff contamination has not been investigated in the Czech Republic. The retention/detention units are of several types, depending on detention time as well as purpose of detention. The suspended solids and other related contaminants can be attenuated in these units.

\section{Oil/grit chambers}

Oil and grit chambers represent a type of retention/detention unit. They are often used in conjunction with highway runoff controls to remove heavy particulates and adsorbed hydrocarbon particulates [5]. Berg (1991) mentions that these structures are intended for small contributing watersheds, usually 1.0 acre or smaller. Maintenance and cleanout are recommended on a quarterly basis, and the associated operating costs are high. If properly maintained, these systems can function as pre-filtering devices for other runoff controls.

Silverman and Stenstrom (1989) acknowledge the relative ineffectiveness of oil and grit chambers. They cite studies which showed that $40 \%$ to $60 \%$ of oil and grease associated with urban runoff are in a dissolved or colloidal state. Thus, classic oil and grit separators which are designed to separate free-floating oil and grease products exhibit low removal efficiencies for urban and highway runoff.

\section{Storage/sediment units}

The primary purpose of storage/treatment units is to control the peak flow associated with the runoff from a catchment. Reduction in the rate of flow can limit the frequency of occurrence of erosion, thereby reducing the sediment load to the receiving waters. The secondary purpose of these units is to store the runoff temporarily and allow the removal of particulate material by settling. The treatment efficiencies depend on the length of the detention time. The length of detention time for a particular runoff event is dependent on the size and intensity of the storm. The ideal detention time for pollutant removal is 24 hours, with a minimum of 6 to 12 hours [6]. Storage of runoff for at least 24 hours may reduce the concentration of particulate materials by $90 \%$ or more.

Detention ponds are most effective for removing particulate constituents and associated materials that are sorbed to suspended solids [4]. Detention ponds are less effective in removing soluble components of runoff, such as nitrate and some phosphorus species. Observed removal of TSS, BOD, total phosphorus, and trace metals were 80-90\%, 20-30\%, $20-30 \%$, and $40-80 \%$ respectively after 12 hours of storage [2].

\section{Methodology}

Various detention/retention units along the Prague-Brno (D1) and Prague-Plzeň (D5) highways in the Czech Republic were selected for monitoring runoff from highways. The Prague-Brno (D1) highway is a divided 6-lane highway with average daily traffic (ADT) in the range 40000-65000 vehicles/day/both directions, whereas the Prague-Plzeň (D5) highway has ADT in the range 16000-22000 vehicles/day/both directions. Various oil/grit chambers and storage/sediment units were identified along the studied highways. These units collect runoff from a $100 \%$ impervious area (highway surface). The oil/grit chambers contain Fibroil filters that are used to adsorb hydrocarbons and oil and greases from the runoff. The storage/sediment units allow runoff constituents to settle under the effect of gravity to reduce suspended solids and their associated constituents. They sometimes contain a Fibroil filter.

The tested sample was collected from the influent highway runoff into the monitored units. Other samples were collected from the effluent from these units. These samples were collected manually with bottles: metal bottles for samples used in hydrocarbon and solids analysis, and plastic bottles for samples used in chloride and zinc analysis. Runoff 
samples for suspended solids and organic analysis were filtered through pre-weighed, pre-combusted glass fiber filters. After drying at $105^{\circ} \mathrm{C}$, the filters were re-weighed to determine the amount of suspended solids in each sample.

This study aims to determine the contribution of ADT and site characteristics to highway runoff quality. It also aims to evaluate the effect of oil/grit chambers and storage/sediment units in the treatment of highway runoff.

\section{Result and discussions}

The contribution of average daily traffic and land use in the concentration of runoff characteristics will be discussed below.

\section{Influence of traffic volume}

Traffic volume would seem to be an important factor predicting runoff quality. In order to study the effect of traffic volume on highway runoff characteristics, we compare the runoff characteristics collected from the D1 and D5, which have different traffic volumes. The tested runoff samples were taken from two detention units along the D1 at stations 72100 and $81450 \mathrm{~km}$, and from two detention units along the D5 in the Rudná and Drahelčice areas. The data are shown in Table 1 . The results indicate no strong or definitive relation-

Table 1: Concentration of runoff constituents from two detention units for each HWY

\begin{tabular}{|c|c|c|c|c|}
\hline \multirow[t]{2}{*}{ Constituents } & \multicolumn{2}{|c|}{$\begin{array}{c}\text { D1 } \\
\text { With } \\
\mathrm{ADT}=40000-65000\end{array}$} & \multicolumn{2}{|c|}{$\begin{array}{c}\text { D5 } \\
\text { With } \\
\text { ADT }=16000-22000\end{array}$} \\
\hline & $72100 \mathrm{~km}$ & $81450 \mathrm{~km}$ & $\begin{array}{c}\text { Rudná } \\
\text { area }\end{array}$ & $\begin{array}{c}\text { Drahel ic } \\
\text { e area }\end{array}$ \\
\hline TSS [mg/l] & 2095 & 2779 & 376 & 1262 \\
\hline VSS $[\mathrm{mg} / \mathrm{l}]$ & 329 & 299 & 122 & 156 \\
\hline $\mathrm{BOD}_{5}[\mathrm{mg} / \mathrm{l}]$ & 7.0 & 6.65 & 7.5 & 15.7 \\
\hline $\mathrm{COD}[\mathrm{mg} / \mathrm{l}]$ & 39.3 & 52 & 46 & 77 \\
\hline $\mathrm{pH}$ & 7.5 & 7.3 & 7.2 & 7.3 \\
\hline $\mathrm{Cl}^{-}[\mathrm{mg} / \mathrm{l}]$ & 961 & 1503 & 93 & 533 \\
\hline $\begin{array}{l}\text { Oil \& Grease } \\
{[\mathrm{mg} / \mathrm{l}]}\end{array}$ & 0.394 & 0.47 & 1.14 & 0.99 \\
\hline $\begin{array}{l}\text { Hydrocar- } \\
\text { bons }[\mathrm{mg} / \mathrm{l}]\end{array}$ & 0.216 & 0.236 & 0.830 & 0.365 \\
\hline
\end{tabular}

ship between BOD, oil and grease, $\mathrm{pH}$, hydrocarbons, or COD on the one hand, and traffic density, on the other. The result indicates that there is a degree of correlation between VSS, TSS and traffic density, but this remains weak.

\section{Influence of site characteristics}

Site characteristics may also affect the amount of pollutants in highway runoff. The effect of parking/washing areas on runoff quality is investigated in this study. Samples from three different sites on the D 5 were selected to study the effect of site characteristics on the concentration of runoff constituents. The first site is a detention unit that collects runoff from a washing station, while the second and third sites are detention units that collect runoff from normal highway sections in the Rudná area and SSÚD No. 8. The results are shown in Fig. 1. The results shown in the figure indicate that the site characteristics have a significant effect on the values of runoff constituents such as total suspended solids, volatile suspended solids, Oil \& Greases, and hydrocarbons. The figure indicates that the runoff constituents from car washing stations are higher than the values from other highway surfaces.

The above results indicate that there is a problem in influent runoff quality to the collection units. Consequently, these units should be prepared to treat runoff or at least attenuate the concentration of its constituents to the specified limit.

The following subsection evaluates oil/grit chambers, which are used mainly in the treatment of organic compounds, and storage/sediment units, which are used in the treatment of suspended solids.

\section{Oil/grit chambers}

To evaluate the performance of oil/grit chambers, we studied one unit collecting runoff from the D1 at $72100 \mathrm{~km}$ and another unit in the Rudná area collecting runoff from the D5. The collected data are shown in Table 2. The table shows the influent and effluent concentration of some constituents, and the removal efficiencies of the constituents using oil/grit chambers.

The results show that an oil/grit chamber is effective in the treatment of organic pollutants such as VSS, BOD, COD, O\&G, and hydrocarbons. The results also show that these retention units are not effective in the treatment of TSS and $\mathrm{Cl}^{-}$. The measured efficiency of these oil/grit chambers in the treatment of organic pollutants may be due to the Fibroil filter that is used. The short retention time as well as the high flow rate in these units may be the reason for the increased values

Table 2: Removal efficiencies using oil/grit chambers for runoff constituents collected from the D1 \& D5 at stations $72100 \mathrm{~km}$, and the Rudná area, respectively

\begin{tabular}{|l|c|c|c|c|c|c|}
\hline \multirow{2}{*}{ Constituents } & \multicolumn{3}{c|}{ D1 } & \multicolumn{3}{c|}{ D5 } \\
\cline { 2 - 8 } & Influent & Effluent & Removal [\%] & Influent & Effluent & Removal [\%] \\
\hline TSS $[\mathrm{mg} / \mathrm{l}]$ & 1074 & 1075 & 0.0 & 376 & 375 & 0.0 \\
\hline $\mathrm{VSS}[\mathrm{mg} / \mathrm{l}]$ & 339 & 315 & 7.0 & 121 & 105 & 13.0 \\
\hline $\mathrm{BOD}_{5}[\mathrm{mg} / \mathrm{l}]$ & 5.24 & 2.98 & 43.0 & 7.5 & 4.7 & 37.0 \\
\hline $\mathrm{COD}[\mathrm{mg} / \mathrm{l}]$ & 36.18 & 24.00 & 34.0 & 46.0 & 32.0 & 30.0 \\
\hline pH & 7.50 & 7.50 & 0.0 & 7.2 & 7.3 & 0.0 \\
\hline $\mathrm{Cl}^{-}[\mathrm{mg} / \mathrm{l}]$ & 357 & 357 & 0.0 & 93 & 92 & 0.0 \\
\hline Oil \& Greases $[\mathrm{mg} / \mathrm{l}]$ & 0.926 & 0.386 & 58.0 & 1.14 & 0.219 & 81.0 \\
\hline Hydrocarbons $[\mathrm{mg} / \mathrm{l}]$ & 0.517 & 0.216 & 58.0 & 0.83 & 0.107 & 87.0 \\
\hline
\end{tabular}



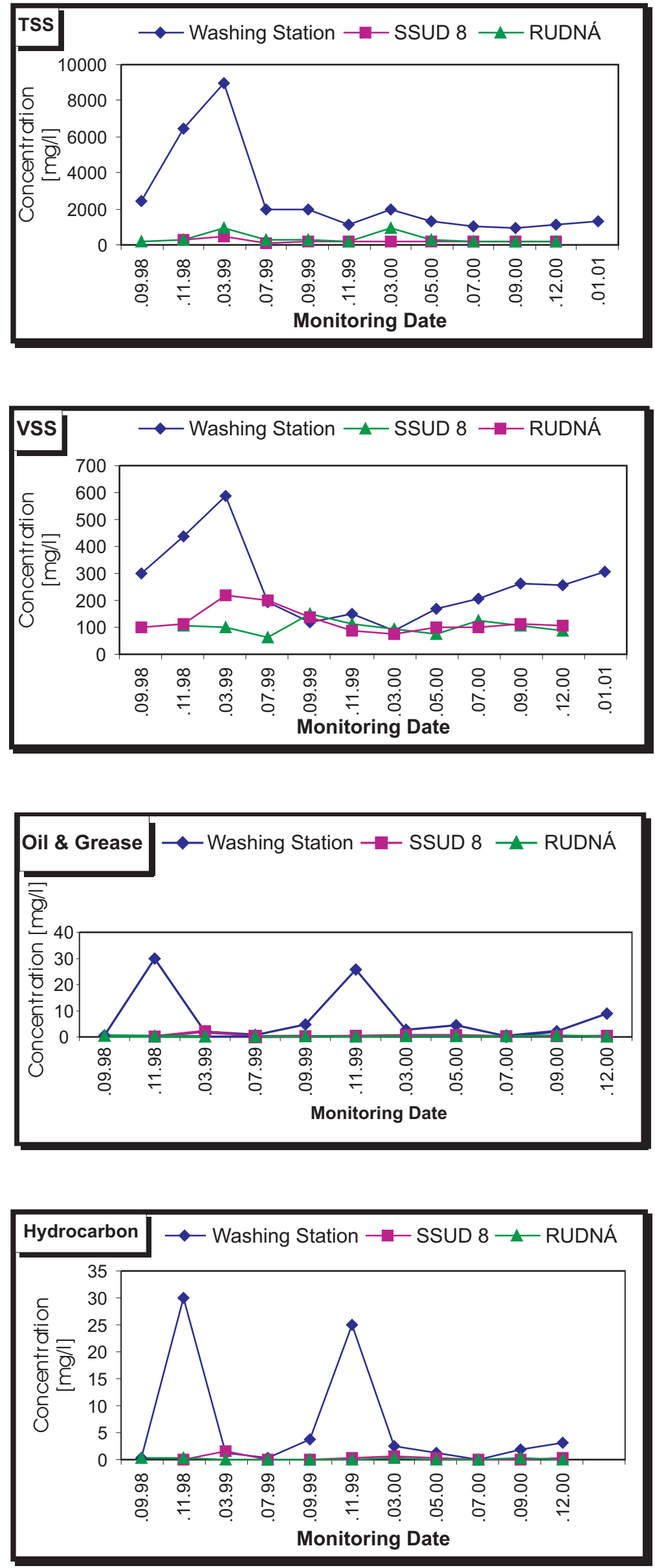

Fig. 1: Runoff constituents collected from various retention/detention units near the D5 

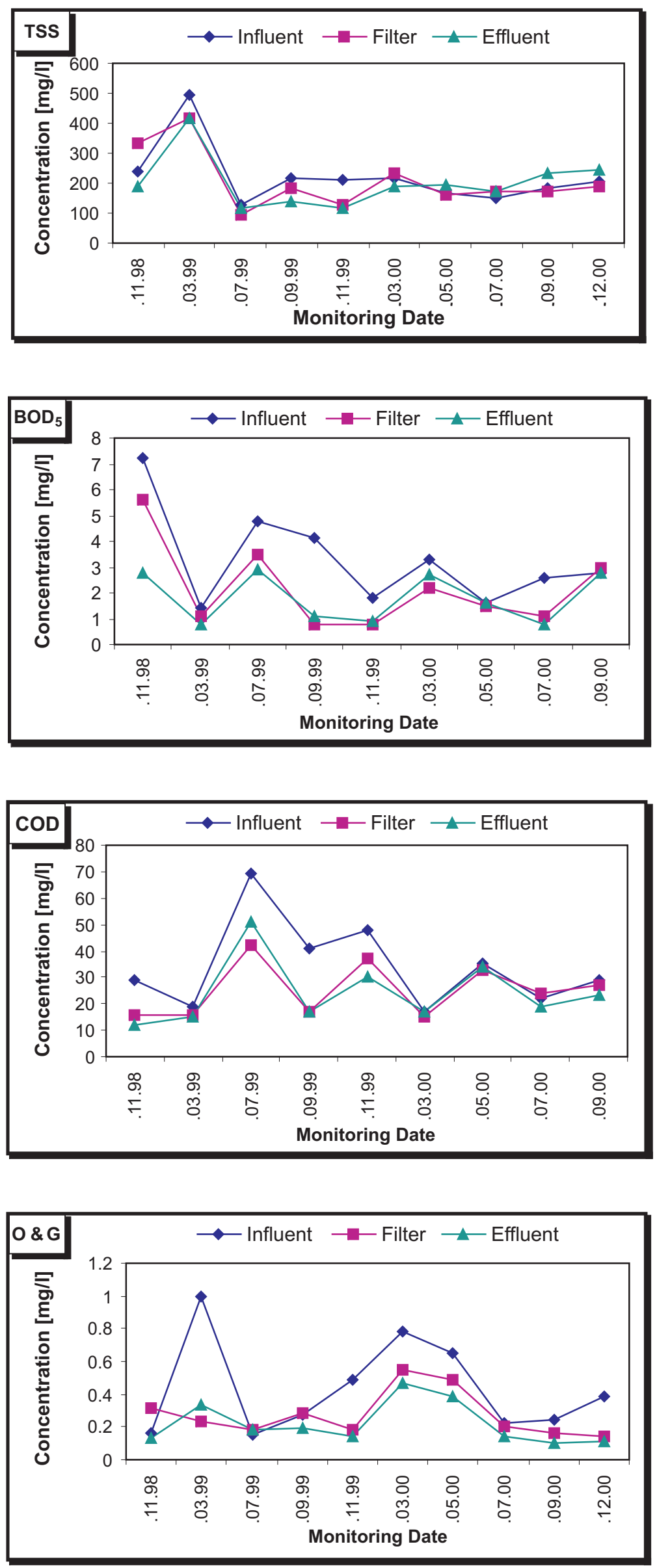

Fig. 2: Runoff constituents for SSÚD No. 8 Storage/sediment unit along the D5 highway 
of TSS, because the flow to these units stimulates some accumulated solids, which may lead to an increase in suspended solids.

\section{Storage/sediment units}

The runoff concentration of the storage/sediment units which collected stormwater runoff near the management and maintenance center (SSÚD No. 8) on highway D5 are shown in Fig. 2. These units are larger than oil/grit chambers to allow the settling of suspended solids, and they also contain a filter using a Fibroil mesh to adsorb organic pollutants. The figure shows the improvement of runoff quality by measuring the influent and effluent concentration for TSS, BOD, COD, and Oil \& Greases. The figure shows that there is a reduction in the concentration of all constituents. The settlement of suspended solids under the effect of gravity during the retention time may be the reason for SS removal. The presence of Fibroil in the settling unit adsorbs organic pollutants and filters some of the suspended solids, and this may explain why there is enhancement of organic pollutants.

\section{Summary and recommendations}

Highway runoff contains total suspended solids, hydrocarbons, oil and greases, chloride, and other contaminants that are transported in solution and particulate forms to adjacent floodplains, roadside swales, and retention/detention ponds. Oil and grit chambers represent a type of the retention/detention unit used for removing heavy particulate and adsorbed hydrocarbon particulates. Storage/sediment units also represent a type of retention/detention unit used to control peak flow and remove suspended solids. This study evaluated the effect of traffic volume and site characteristics on highway runoff quality. It also evaluated the performance of the retention/detention units that collect runoff from the Prague-Brno and Prague-Plzeň highways, Czech Republic.

Analysis of the results indicates that there is no definitive relationship between average daily traffic and concentration of runoff constituents, as was concluded in other preceding studies [3], [8]. The results also show that the retention/detention units used in this study are effective in treating organic compounds, but are less effective in treating suspended solids, perhaps due either to the small size of these retention units, or to the short retention time inside it. Consequently this study can make the following recommendations:

- decrease the flow rate into the studied units by any suitable method, in order to allow the settling of suspended solids;

- use a sand filter or densely vegetative swales before the runoff enters the studied units;

- study the effectiveness of a lower flow rate in the treatment of suspended solids.

\section{Acknowledgement}

We would like to thank and express our appreciation to Ing. K. Slavíčková and all members of the sanitary engineering department for their help. This Research has been supported by grant No.: VZ J04198: 2111100005.
BOD biochemical oxygen demand

$\mathrm{Cl}^{-}$chloride

$\mathrm{O} \& \mathrm{G}$ oil and grease

\section{References}

[1] Berg, V. H.: Water Quality Inlets (Oil/Grit Separators). Maryland Department of the Environment, Sediment and Stormwater Administration, Baltimore, MD, 1991

[2] Dorman, M. E., Hartigan, J., Steg R.: Retention, Detention, and Overland Flow for Pollutant Removal from Highway Stormwater Runoff. Vol. I: Research Report, FHWA-RD-96-095, Versar Inc., Springfield, VA, 1996

[3] Driscoll, E. D., Shelley, P. E., Strecker, E. W.: Pollutant Loadings and Impacts from Highway Stormwater Runoff. Vol. II: Analytical Investigation and Research Report, Federal Highway Administration, Office of Research and Development Report No. FHWA-RD-88-008, 1990

[4] Schueler, T. R., Kumble, P. A., Heraty, M. A.: A Current Assessment of Urban Best Management Practices, Techniques for Reducing Non-Point Source Pollutant in the Coastal Zone. Metropolitan Washington Council of Governments, Washington, DC, 1992

[5] Schueler, T. R., Kumble, P. A., Heraty, M. A.: A Current Assessment of Urban Best Management Practices, Techniques for Reducing Non-Point Source Pollution in the Coastal Zone. Department of Environmental Programs, Metropolitan Washington Council of Governments, Washington, DC, 1991

[6] Schueler, T. R.: Controlling Urban Runoff: A Practical Manual for Planning and designing Urban BMPs. Department of Environmental Programs, Metropolitan Washington Council of Governments, Washington, DC, 1987

[7] Silverman, G. S., Stenstrom, M. K.: Source Control of Oil and Grease in an Urban Area. Proceedings of an Engineering Foundation Conference on Current Practices and Design Criteria for Urban Quality Control, ASCE, New York, NY, 1989, pp. 403-420

[8] Stotz, G.: Investigations of the Properties of the Surface Water Runoff from a Federal Highway in FRG. The Science of the Total Environment, Vol. 59, 1987, pp. 329-337

Eng. Ashraf El-Shahat Elsayed, MSc. e-mail: ashraf@fsv.cvut.cz

Prof. Ing. Alexander Grünwald, CSc. Department of Sanitary Engineering Czech Technical University in Prague Faculty of Civil Engineering Thákurova 7, 16629 Praha 6, Czech Republic

Dalibor Dvořák,

Road and Motorway Directorate of Czech Republic Na Pankráci 546, 14000 Praha 4, Czech Republic

\section{List of abbreviation}

TSS total suspended solids

VSS volatile suspended solids

COD chemical oxygen demand 